\title{
SOCIAL RESPONSIBILITY OF ENTERPRISES TOWARDS EMPLOYEES. THEORETICAL AND PRACTICAL ASPECTS
}

\author{
AGNIESZKA KWARCIŃSKA \\ University of Szczecin, Faculty of Management and Economics of Services, POLAND \\ e-mail: agnieszka.kwarcinska@wzieu.pl
}

RECEIVED
ACCEPTED
JEL
CLASSIFICATION

KEYWORDS

ABSTRACT
10 December 2018

28 December 2018

A13, M12, M14

Corporate Social Responsibility, employees, relations with employees

The article presents theoretical and practical considerations related to the implementation of Corporate Social Responsibility (CSR) in the area of relations with employees. Its purpose is to analyse basic principles, guidelines and standards of this concept with regard to employees and also to attempt to evaluate this type of activity in Polish reality. For the purpose of this objective, the modern sense of social responsibility of enterprises is presented first. Subsequently, selected documents that determine normative guidelines for this concept have been considered among which those that mention employee-related aspects have been distinguished. The last part of the article contains results of research conducted in enterprises that provide accommodation services in Zachodniopomorskie province, this research concerns their involvement in CSR activities with respect to employees. A summary of theoretical assumptions and practical functioning of the enterprises surveyed enabled finding divergence and indicating the scope of possible action.

\section{Introduction}

The concept of social responsibility of business, which is also referred to as Corporate Social Responsibility (CSR), is a term with enormous significance relating to activities taken by enterprises in various fields. This article focuses on one of the aspects of CSR, which refers to employees. The purpose of this article is an analysis of basic principles, guidelines and standards of this concept with respect to employees, and to attempt to evaluate this 
kind of activity in the Polish reality. For the purpose of this objective, the modern sense of social responsibility of enterprises is presented first. Then, selected documents that determine normative guidelines for this concept are considered among which those that mention employee-related aspects have been distinguished. The last part of the article contains results of the survey conducted in enterprises that provide accommodation services in Zachodniopomorskie province, these surveys concern their involvement in CSR activities with respect to employees.

\section{Modern determination of social responsibility of business}

Although the concept of social responsibility of business (enterprises), also referred to as Corporate Social Responsibility (CSR), is rooted in the virtues of trust and charity work (Mazur-Wierzbicka, 2012, p. 12), it is not currently limited only to philanthropy. It is constantly evolving and has gained a broad meaning in organisational management strategy. Reasons that reinforce these transformations are, among others, social, economic and environmental issues, and especially all issues of social inequality and poverty, profound and dynamic globalisation process, and the condition of the natural environment. It should also be noted that this concept directly corresponds with a significant and widely-accepted idea of sustainability that derives from a sense of concern about the right of future generations to develop. ${ }^{1}$

In subject literature, the concept of corporate social responsibility is variously defined. Some of these definitions stress a wide sense of functioning of enterprises, which goes beyond economic profitability, thus beyond the responsibility towards only the owners or shareholders. In this case, the significance of functioning of each organisation in a determined environment and the influence of its decisions and behaviour on all entities that deal with it are indicated (Reyes, 2005, pp. 15-16). When defining CSR, at least two of its dimensions are distinguished: internal and external. In the former, according to G. Bartkowiak (2011, p. 25), safety in the workplace, human resources management, resource management and influence of business activity on environment are significant. In turn, the external dimension contains: influence on local communities, relations with business associates and respect for the human rights. The conventional classifications of particular CSR aspects probably provide order, but primarily, they consider the influence of an organisation on a large group of entities treated as stakeholders. Thus, there are many definitions of CSR, which stress the significance of different groups of stakeholders. According to these definitions, the corporate social responsibility is based on voluntary consideration of the interest of any stakeholder organization (Klimek, 2011, p. 270; Szczepańska, 2011, p. 177). The stakeholder groups are most often determined as employees, customers, contractors, local communities and the natural environment. Therefore, a socially-responsible enterprise, when making a decision and conducting economic activities, considers the interests of various groups of entities. It becomes responsible for them in a moral sense and it considers their well-being. In practice, this means creating and maintaining proper relations with them. Proper communication, understanding and adequacy of solutions are therefore necessary. According to B. Rok (2013, p. 97), multi-dimensional activity towards various groups of stakeholders focuses on four levels of participation: informing, consulting, making joint decisions and performing joint activities. Indeed, to reach a level of common and mutual relations, it is extremely important to first acquire, process and share information and then to express the will to communicate and accept one another. These objectives are so multidimensional that performance of the modern CSR concept leans towards integration with corporate management strategy or it becomes its superior determinant.

\footnotetext{
1 To learn more Kwarcińska (2016), pp. 95-103.
} 
As it is shown, conscious and voluntary actions that consider the involvement of particular stakeholders constitute the core of many fields of corporate responsibility. One of the most significant of them is responsibility for employees, the aspects of which are emphasised in the basic guidelines of social responsibility.

\section{Normative principles of corporate social responsibility in the area of relations with employees}

The basic guidelines of the CSR concept considered in the international discourse, debates and initiatives function as formalised normative provisions. ${ }^{2}$ They constitute certain directions for conduct. They consider numerous aspects of universal responsibility of various organisations, including their responsibility with respect to employees. Among them, the most important are: OECD Guidelines for Multinational Enterprises, provisions of Global Compact ISO 26000 Standard, SA 8000 Standard and also AA1000SES Standard. Each of the abovementioned documents contains provisions related to the issues of employees, whether direct or indirect. Thus, they contain all general requirements or outline particular requirements, or they provide particular actions regarding the assumption of responsibility for employees.

OECD guidelines refer to issues related to employees in a few areas such as: information transparency, human rights, employment, and professional relationships (OECD Guidelines..., 2013; Makuch, 2011, pp. 10-14). The first one is related to the fact that enterprises should disclose data regarding their activity. Clearly, such a general statement may be applied to the employees, since they should be the first to know about any activity of an enterprise, in which they are employed. The second area, human rights, indicates the necessity to conduct activities with a sense of respect for human rights and to search for ways to prevent or alleviate adverse results of breaches of these rights. Another area concerning employment and professional relationships corresponds directly with relations with employees. Here, provisions indicate freedom to associate, a right to negotiate collective agreements, abolishment of child labour, elimination any forms of forced or compulsory work and abolishment of any discriminatory practices in the area of employment or professional activity. These guidelines clarify the image of an enterprise that assumes responsibility for its employees.

Also, the fulfillment of Global Compact principles corresponds with consideration of widely-understood adequate relations with employees. These principles, similarly to OECD guidelines, are related to both supporting and protecting human rights and freedom of association and the necessity to eliminate any form of compulsory work and to take action to abolish of child labour (Kietliński, Reyes, Oleksyn, 2005, pp. 152-153). Although these indications for management, which are of a strong normative nature, constitute a set of directions of operation desired by societies and the economic world, they do not force business entities to strictly follow them. It should be stressed each time that the entrepreneurs may voluntary follow these principles by assuming an obligation of responsibility for various stakeholders, including employees.

Apart from the above-mentioned provisions concerning general principles of conducting the business activity in a responsible manner, also with respect to employees under the CSR concept, other provisions, developed for more practical application by enterprises may also be indicated. Those that should be mentioned are the ISO 26000 Standard mentioned above, which concerns social responsibility (Guidance on social responsibility). It is a set of practical guidelines regarding employee-related issues. Activities within the scope of these guidelines include (ISO 26000..., 2014):

\footnotetext{
2 To learn more Kwarcińska (2016), pp. 95-103.
} 
a) human rights, among which the most important are the following issues: due diligence, situations of threat to human rights, avoidance of participation, consideration of complaints, discrimination and sensitive groups, citizen's, personal and political rights, economic laws, fundamental principles and rights at work;

b) work practice, where employment and employment relationship, work conditions and social security, social dialogue, work health and safety, human development and training in the workplace are important.

It should be noted that with a high level of detail, the ISO 26000 Standard remains universal. Thereby, not only enterprises may be its addressees, but also a wide group of organisations that wish to voluntarily assume a moral obligation in the form of responsibility.

Another documents developed for practical application of CSR principles by enterprises, also with respect to employees, are: SA8000 Standard - Social Responsibility and AA1000SES Standard - Stakeholder Involvement Standard. The former refers to employee-related aspects with consideration of requirements of social responsibility of enterprises with respect to, i.a. (Norma SA8000): child labour, compulsory or mandatory work, health and safety, freedom of association and the right of collective bargaining, discrimination, work discipline, working hours, and compensation. The latter, AA1000SES Standard, constitutes guidelines that are important from the point of view of formal aspects of creating solid relations of organisations with various groups of stakeholders, certainly including employees, and also those who cannot speak for themselves, such as: the natural environment or future generations. According to AA1000SES Standard, the process of involving the stakeholders consists of four stages of conduct with respect of them (Standard AA1000SES):

1. Planning, where the most important are: profiles and classification of stakeholders, determination of level and methods of involvement, determination and notification about transparency boundaries, development of the involvement plan, determination of indexes.

2. Preparation, including: resource mobilisation, creating new possibilities for development, identification and preparation for an involvement-related risk.

3. Implementation and in particular situations: encouraging the stakeholders to become involved, informing the stakeholders, involvement, documenting the involvement and its results, developing an action plan, presentation of results of involvement and the action plan.

4. Review and improvement including: involvement evaluation and monitoring, conclusions and improvement, summary of the action plan, involvement report.

As far as application of particular actions with respect to the stakeholders is concerned, both documents constitute incredibly helpful, ordered and transparent codes of conduct and improvement of their involvement. The fundamental value in all provisions is always a widely-understood responsibility and the principle of voluntariness.

\section{Practical stage of relations with employees within the scope of implementation of CSR concept on the example of survey among the enterprises that provide accommodation services in Zachodniopomorskie province}

The research on relations with employees was a part of the exploration of the level of involvement in pursuing the CSR concept, which was conducted on a randomly selected micro, small and medium companies that provide accommodation services in Zachodniopomorskie province, within the scope of an international project. ${ }^{3}$ In order

${ }^{3}$ Empirical data presented in the article constitute only a part of research results that had an extensive analytical context that includes issues related to CSR and innovation and Polish-German integration. The research was conducted in 2016 under 
to examine the involvement of employees, five statements were proposed, which determine basic activities based on CSR in relations with employees. The companies were to address these statements by determining the level of their implementation in a five-point scale of activity. The range of the scale included evaluation starting from determination that a given activity is not being conducted at all, through consulting that the activities proposed are performed marginally, partially or mostly, ending with confirmation of full involvement of the enterprise within a given scope. The results of this research are presented below in following pictures that indicate the percentage of responding entities.

The first statement referred to the existence of complex principles of conduct in the matter of restricting and preventing risks of loss of health of employees in the enterprise. According to the research, the results of which are presented in Figure 1, nearly half of the enterprises surveyed have developed such principles. Additionally, 12\% of the enterprises surveyed indicated that these principles have been adopted for the most part. One fifth declared that these principles are not being implemented at all.

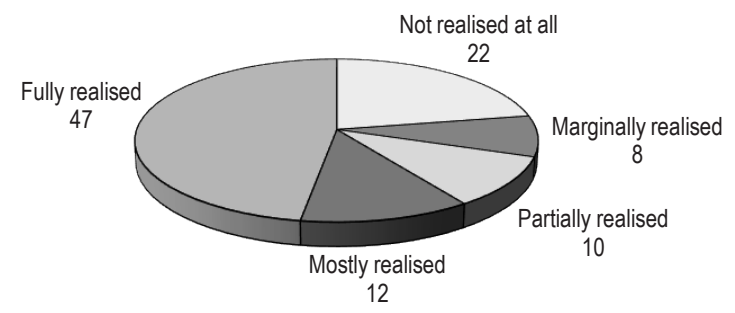

Figure 1. Our enterprise has developed complex principles of conduct to limit or prevent the risk of health loss of our employees (\%)

Source: own work on the basis of: Bretyn (2016), pp. 61-89.

Then, a question was asked about the extent, to which the enterprise provides a possibility for further professional development, or when necessary, retraining, for all its employees. According to the results presented in Figure 2, only $16 \%$ of the enterprises surveyed present a full activity in this matter, and $34 \%$ of them do not provide its employees with any educational possibilities at all.

Another aspect concerned encouraging the employees to become involved in charity. According to these results presented in Figure 3, one quarter of the enterprises surveyed presented full involvement in this area, whereas nearly $40 \%$ of them do stimulate their employees in this field of activity.

Another statement referred to the system of managing complaints and suggestions, and ideas for change initiated by employees. According to analyses of indications of enterprises surveyed presented in Figure 4, nearly $40 \%$ of them declare that they possess such a system. At the same time it was found, that nearly $30 \%$ of the enterprises in this research group do not possess any such system at all.

\footnotetext{
a project supported by Polsko-Niemiecka Fundacja na Rzecz Nauki oraz Ministerstwo Nauki i Szkolnictwa Wyższego (Polish-German Foundation for Science and the Ministry of Higher Education) "Corporate Social Responsibility as a tool for innovation and integration of Polish and German micro, small and medium enterprises. Analysis. Recommendations". Results of this research were published in a monography: Wolska, Kwarcińska, Warszycki (2016).
} 


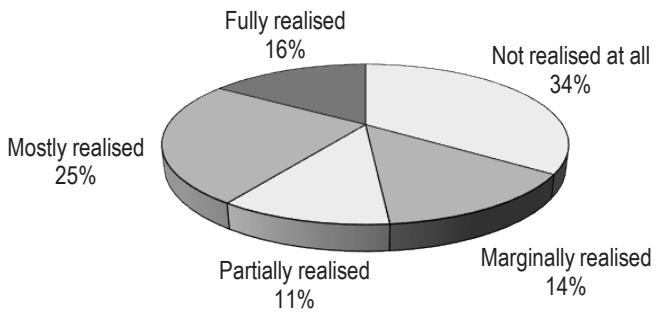

Figure 2. Our enterprise provides a possibility for further professional education, or when necessary, retraining for all its employees

Source: own work on the basis of: Bretyn (2016), pp. 61-89.

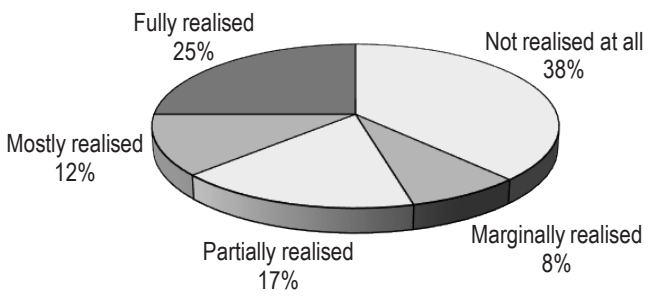

Figure 3. Our enterprise encourages our employees to become involved in charity

Source: own work on the basis of: Bretyn (2016), pp. 61-89.

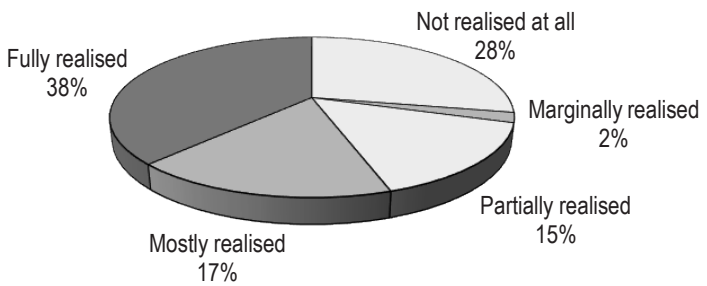

Figure 4. There is a system of managing complaints and suggestions, propositions of change by employees in our enterprise Source: own work on the basis of: Bretyn (2016), pp. 61-89.

The last issue is related to involvement of enterprises in supporting their employees in keeping the balance between their private and professional life. The research results in this area presented in Figure 5 show that slightly over $30 \%$ of participating entities fully support their employees whereas $17 \%$ mostly support their employees on that matter. The results also showed that $27 \%$ of the participants surveyed do not conduct any such activity at all. 


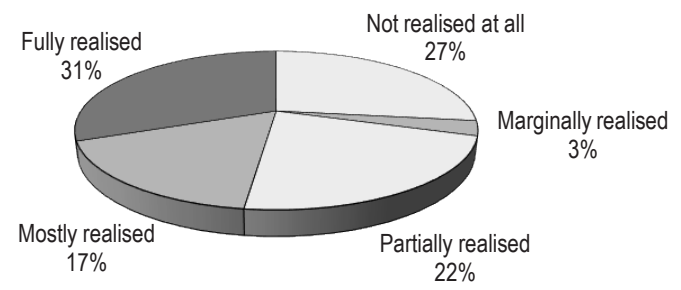

Figure 5. Our enterprise supports its employees in keeping the balance between private and professional life. (work-lifebalance) e.g. through flexible working hours

Source: own work on the basis of: Bretyn (2016), pp. 61-89.

\section{Conclusions}

Modern development of the meaning of corporate social responsibility stresses its high value for functioning and development of each enterprise. Currently, building a competitive advantage and a solid organisation requires a widely-understood cooperation and the assumption of conscious responsibility. The boundaries of such moral obligation extend to and include respecting the interests of many stakeholders. This is indubitably a difficult task that often causes conflict. The employees occupy a very important position among these groups. It is the employees that create the basic development potential and cooperation with them should be based, above all, on understanding, honesty, trust and respect.

Ideological grounds for respect, support, and ensuring safety and protection of employees, which have already found their place in normative provisions, have not yet been fully reflected in the practical functioning of enterprises. The presented research results of the enterprises that provide accommodation services in Zachodniopomorskie province enabled, above all, the observation of a relatively average fulfillment of principles of corporate social responsibility in these enterprises within the scope of their involvement in relations with their employees. The justification for this statement is the fact that nearly half of the participating enterprises confirmed that they fully or mostly conduct activities regarding: developing complex operational plans in order to limit or prevent the risk of loss of health by employees, creating a system of managing complaints and suggestions, propositions of change by employees and supporting employees in keeping a balance between their private and professional life. At the same time, approximately $40 \%$ of enterprises involved in this research declared that they fully or mostly ensure possibilities for further professional education, or if necessary, for retraining of all employees and also encourage their employees to become involved in charity work.

It may be therefore be stated that there are flaws within the scope of the application of voluntary solutions in the practical functioning of enterprises, which include solutions stressing that these enterprises assume responsibility for their employees. As it seems, the main reason for this is, primarily, insufficient awareness of the benefits deriving from assuming these duties. Thus, all educational, promotional and stimulating activities are justified. 


\section{References}

Bartkowiak, G. (2011). Społeczna odpowiedzialność biznesu w aspekcie teoretycznym i empirycznym. Warszawa: Difin.

Bretyn, A. (2016). Wyniki badań. In: G. Wolska, A. Kwarcińska, P. Warszycki (eds.) (2016) Społeczna odpowiedzialność biznesu narzędziem innowacyjności i integracji polskich i niemieckich mikro, małych i średnich przedsiębiorstw. Analiza. Rekomendacje, Soziale Unternehmensverantwortung als Innovations- und Integrationsinstrument Deutscher und Polnischer Kleinstunternehmen und KMUS. Ist-Stand-Analyse und Handlungsempfehlungen. Rostock: Hanseatic Institute for Entrepreneurship and Regional Development an der Universität Rostock e.V.

ISO 26000 Społeczna odpowiedzialność (2014). Retrieved from: www.pkn.pl/sites/default/files/discovering_iso_26000.pdf.

Kietliński, K., Reyes, V.M, Oleksyn, T. (2005). Etyka w biznesie i zarządzaniu. Kraków: Oficyna Ekonomiczna.

Klimek, J. (2014). Etyka biznesu. Teoretyczne założenia, praktyka zastosowań. Warszawa: Difin.

Kwarcińska, A. (2016). Międzynarodowe inicjatywy normatywne w zakresie społecznej odpowiedzialności biznesu (CSR) jako wyraz działań na rzecz zrównoważonego rozwoju. Prace Naukowe Uniwersytetu Ekonomicznego we Wrocławiu, 416, 95-103.

Makuch, Ł. (2011). Normy i standardy społecznej odpowiedzialności biznesu (CSR). Przewodnik po kluczowych standardach społecznej odpowiedzialności biznesu oraz relacjach i współzależnościach pomiędzy nimi zachodzących. Warszawa.

Mazur-Wierzbicka, E. (2012). CSR w dydaktyce, czyli jak uczyć studentów społecznej odpowiedzialności. Szczecin: Stowarzyszenie Kreatywni dla Szczecina.

Norma SA8000 Społeczna odpowiedzialność (2018). Retrieved from: https://www.mpit.gov.pl.

OECD Guidelines for Multinational Enterprises 2011 Edition (2013).OECD Publishing. DOI: org/10.1787/9789264115415-en.

Reyes, V.M. (2005). Etyka biznesu - wybrane kwestie. In: K. Kietliński, V.M. Reyes, T. Oleksyn, Etyka w biznesie i zarządzaniu. Kraków: Oficyna Ekonomiczna.

Rok, B. (2013). Podstawy odpowiedzialności społecznej w zarządzaniu. Warszawa: Wydawnictwo Poltext.

Standard AA1000SES (2018). Zaangażowanie Interesariuszy, pp. 22-43. Retrieved from: www.academia.edu.

Szczepańska, K. (2011). Zarządzanie jakością. W dążeniu do doskonałości. Warszawa: C.H. Beck.

Wolska, G., Kwarcińska, A. Warszycki P. (eds.) (2016) Społeczna odpowiedzialność biznesu narzędziem innowacyjności i integracji polskich i niemieckich mikro, małych i średnich przedsiębiorstw. Analiza. Rekomendacje, Soziale Unternehmensverantwortung als Innovations- und Integrationsinstrument Deutscher und Polnischer Kleinstunternehmen und KMUS. Ist-Stand-Analyse und Handlungsempfehlungen. Rostock: Hanseatic Institute for Entrepreneurship and Regional Development an der Universität Rostock e.V.

Cite this anticle aS: Kwarcińska, A. (2018). Social responsibility of enterprises towards employees. Theoretical and practical aspects. European Journal of Service Management, 4 (28/2), 223-230. DOI: 10.18276/ejsm.2018.28/2-28. 